\title{
On the Presentation Time and Latent Time for Reaction to Gravity in Fronds of Asplenium bulbiferum.
}

\author{
BY \\ F. M. O. WAIGHT \\ (Associate of University College, Reading). \\ With one Diagram in the Text.
}

$\mathrm{T}^{\mathrm{T}}$ has already been shown ${ }^{1}$ that fronds of Asplenium bulbiferum are I negatively geotropic, and further that the specific irritability is not constant throughout their development.

In I92I Miss Prankerd suggested to me that some measure of the intensity of this irritability might be gained by ascertaining the presentation time at different stages of development, and this I have attempted to do under her direction.

The presentation time as defined by ${\mathrm{C} z a p e{ }^{2}}^{2}$ is the shortest period of stimulation which will produce any response on the klinostat, and the latent time is the period elapsing between the beginning of stimulation and the first indication of response. In this case, therefore, the presentation time is the period of horizontality necessary to secure the slightest movement upwards of the frond, and the latent time is the period from the beginning of horizontality to the moment when the movement is just visible. The first two stages in the development of the frond previously noted, ${ }^{3}$ namely, Infant, when the leaflets are in the apical coil, and Adolescent, when the leaflets are unfolding, have been further subdivided into Early Infant, fronds $0.8-3.0 \mathrm{~cm}$.; Middle Infant, fronds $3 \cdot 0-5.5 \mathrm{~cm}$.; Late Infant, fronds over $5.5 \mathrm{~cm}$. with no leaflets unfolded; and Adolescent I, 2, 3, \&c., according to the number of pairs of leaflets unfolded from the apical coil.

The ferns were grown in a greenhouse, and although it was impossible

1 Prankerd, T. L. (1922): On the Irritability of the Fronds of Asplenium bulbiferum, with Special Reference to Graviperception. Proc. Roy. Soc., B., xciii.

${ }^{2}$ Czapek (1898): Jahrb. f. wiss. Bot., xxxii.

${ }^{3}$ Prankerd: loc. cit., p. I44.

[Annals of Botany, Vol. XXXVII. No. CXLV. January, 1923.] 
to keep the temperature constant, readings were taken morning and evening on a maximum and minimum thermometer. Readings of the relative humidity, which could be kept fairly constant at $80-90$ per cent., were also recorded daily.

For stimulation the fronds were placed horizontally on their sides, and adaxially to the incident light. ${ }^{1}$ In order to see if any movement had occurred, the outline of the frond was traced on glass, almost in contact with it, unless this was impracticable on account of epinastic curvature, when the frond was placed against a scale and its position read as exactly as possible through a pin-hole. At the end of the period of stimulation, the plant was either rotated on the klinostat, or, when this was impossible owing to the size or weight of the pot, it was placed so that the frond was quite vertical. The following tables, made from actual experiments, typical of a large number, show that any difference in the results obtained by the two methods is inappreciable:

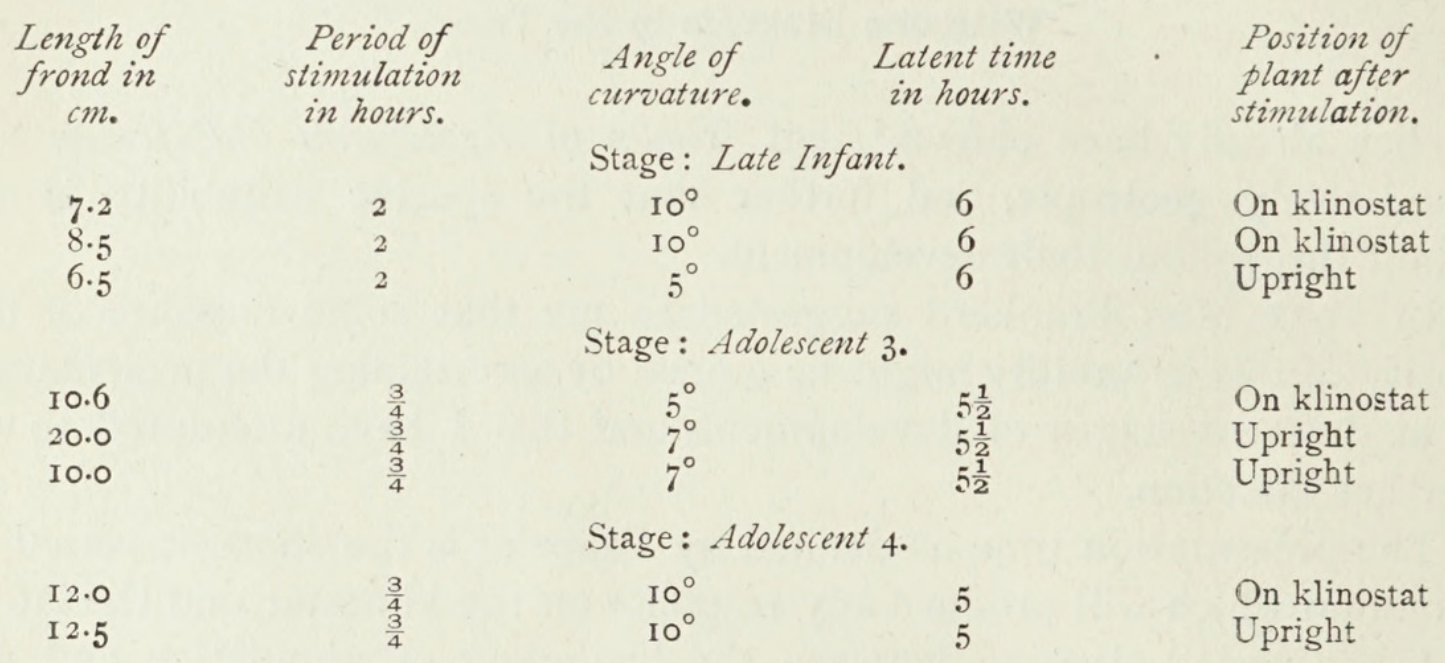

When upwards of four hundred experiments had been carried out in this way, an approximate idea was gained of the presentation time at the various stages above mentioned. Several critical experiments for each stage were then made when the temperature was as nearly as possible $20^{\circ} \mathrm{C}$. (never above $2 \mathrm{I}^{\circ} \mathrm{C}$. or below $19^{\circ} \mathrm{C}$.). The angle recorded was in every case the maximum reached, and the results of these experiments were checked by those where no curvature took place with the same or somewhat lower periods of stimulation. This is important, as exposures much in excess of the presentation time often produce movements of little or no greater amplitude.

Column $I$ in the tables shows that considerable difference in the length of the frond does not affect the presentation time and latent time. It has been found that these periods depend on the stage, and only indirectly on the age or length of the frond.

1 The reasons for this position have already been given. Prankerd: loc. cit., p. I 45 . 


\section{Reaction to Gravity in Fronds of Asplenium bulbiferum. 57}

After about eight pairs of leaflets are unfolded, the presentation time is much more difficult to measure, owing to the fact that all the varied types of movement previously ${ }^{1}$ described may, and often do, take placesome to an increased degree-until maturity is reached. Nutation is probably at its maximum, and, although varying greatly in amount, may be as much as $20^{\circ}$ right and left of the vertical. Growth in the dark of course avoids heliotropism, and control experiments have been made in a dark room; but here constant conditions, particularly the important one of temperature, could not usually be obtained.

Physiological variability of individual fronds finds expression in the different angular heights attained; for however morphologically similar several fern fronds may be, they will almost certainly not behave identically under precisely similar conditions. Hence the presentation times deduced should be regarded as those periods which, under the given conditions, will generally produce movements of about $5^{\circ}$ and only very rarely exceeding $10^{\circ}$.

Tables showing results of experiments at various stages of the frond's development.

Temperature $20^{\circ} \mathrm{C}$. (approx.); humidity $85 \%$ (approx.).

P. T. $=$ presentation time .

L. T. = latent time.

Stage: Early Infant (apical coil just above soil level).

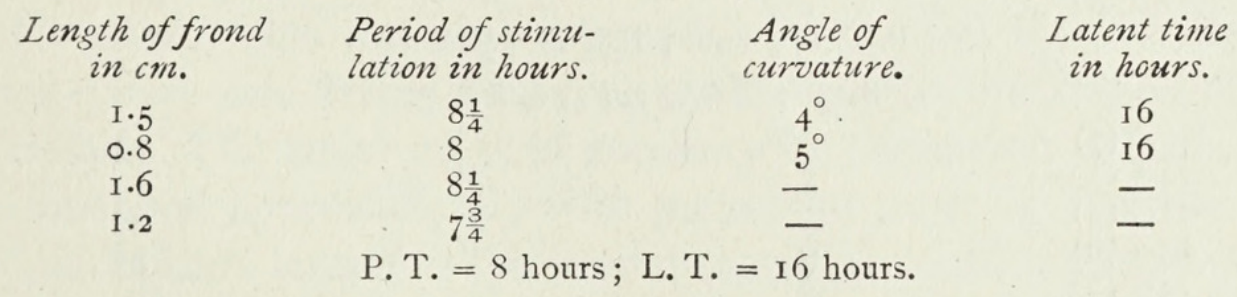

Stage: Early Infant (apical coil about a centimetre above the soil).

$\begin{array}{cccc}\mathrm{I} \cdot 5 & 4 & 10^{\circ} & \text { 10 } \\ \mathrm{I} \cdot 5 & 4 & 50^{\circ} & 10 \\ \mathrm{I} \cdot 5 & 4 & 4 & \text { 10 } \\ 2 \cdot 3 & 4 & - & - \\ 2 \cdot 7 & 3 \frac{1}{2} & - & - \\ 2.6 & 3 & & \end{array}$

P. T. $=4$ hours; L. T. $=10$ hours.

Stage: Middle Infant.

$\begin{array}{llrl}5 \cdot 2 & 3 & 11^{\circ} & 7 \frac{1}{2} \\ 5 \cdot 0 & 3 & 10^{\circ} & 8 \\ 3 \cdot 0 & 3 & 7^{\circ} & 9 \\ 3 \cdot 4 & 3 & 5 & 9 \\ 3.8 & 3 & 5^{\circ} & 7 \frac{1}{2} \\ 3 \cdot 0 & 3 & - & - \\ 3.0 & 3 & - & -\end{array}$

P. T. $=3$ hours; L. T. $=8$ hours.

${ }_{1}^{1}$ Prankerd : loc. cit., p. I44. 
${ }^{8}$ Waight.-On the Presentation Time and Latent Time for

Stage : Late Infant.

\begin{tabular}{|c|c|c|c|}
\hline $\begin{array}{l}\text { Length of frond } \\
\text { in cm. }\end{array}$ & Period of stimu- & $\begin{array}{l}\text { Angle of } \\
\text { curvature. }\end{array}$ & $\begin{array}{l}\text { Latent tim } \\
\text { in hours. }\end{array}$ \\
\hline $\begin{array}{c}\text { in cm. } \\
6.5\end{array}$ & lation in hours. & $15^{\circ}$ & $\begin{array}{c}2 n \text { hours. } \\
5 \frac{1}{2}\end{array}$ \\
\hline $6 \cdot 5$ & 2 & $10^{\circ}$ & \\
\hline $7 \cdot 2$ & 2 & $10^{\circ}$ & 5 \\
\hline 8.5 & 2 & $10^{\circ}$ & 6 \\
\hline 6.5 & 2 & $5^{\circ}$ & 7 \\
\hline $7 \cdot 0$ & 2 & $5^{\circ}$ & 7 \\
\hline $5 \cdot 5$ & 2 & - & - \\
\hline \multicolumn{4}{|c|}{$\begin{array}{c}\text { P. T. }=2 \text { hours } ; \text { L. T. }=6 \text { hours. } \\
\text { Stage: Adolescent I. }\end{array}$} \\
\hline $7 \cdot 5$ & $1 \frac{1}{2}$ & $10^{\circ}$ & $6 \frac{1}{2}$ \\
\hline 6.5 & $1 \frac{1}{2}$ & $8^{\circ}$ & 5 \\
\hline $7 \cdot 5$ & $\mathrm{I}_{2}^{1}$ & $7^{\circ}$ & $5 \frac{1}{2}$ \\
\hline $5 \cdot 0$ & $1 \frac{1}{2}$ & - & - \\
\hline $7 \cdot 7$ & $\mathrm{I} \frac{1}{2}$ & - & - \\
\hline \multirow{2}{*}{\multicolumn{4}{|c|}{$\begin{aligned} \text { P. T. }= & \mathrm{I}_{2}^{\frac{1}{2}} \text { hours } ; \text { L. T. }=5 \frac{1}{2} \text { hours. } \\
& \text { Stage: Adolescent } 2 .\end{aligned}$}} \\
\hline & & & \\
\hline $8 \cdot 5$ & 1 & $\mathrm{I} 3^{\circ}$ & 5 \\
\hline $\mathrm{II} \cdot 2$ & I & $10^{\circ}$ & \\
\hline $8 \cdot 0$ & I & $9^{\circ}$ & $6 \frac{1}{2}$ \\
\hline 8.0 & I & $7^{\circ}$ & $5 \frac{1}{2}$ \\
\hline
\end{tabular}

Stage : Adolescent 3 and 4 . (Number of pairs of leaflets unfolded placed in brackets after length in this and the next table.)

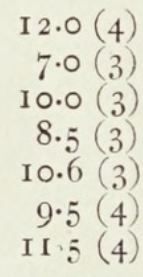

I $6.0(7)$

$14.5(5)$

$2 \mathrm{I} \cdot 5(5)$

I $3 \cdot 2$ (6)

$24 \cdot 5(7)$

I $7.7(5)$

I 2.0 (6)

20.2

I $3 \cdot 0$

I $3 \cdot 7$

$\mathrm{I} \mathrm{J} \cdot \mathrm{7}$

20.0

I 8.0

I $5 \cdot 7$

$2 \mathrm{I} \cdot 2$

I 8.5

I 9.5

I 8.3

I 4.0

$28 \cdot 5$

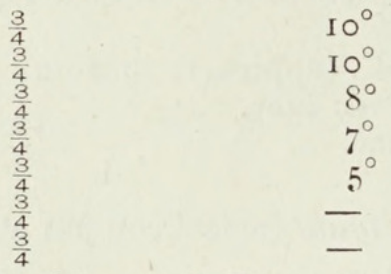

P. T. $=\frac{3}{4}$ hour ; L. T. $=5 \frac{1}{2}$ hours.

Stage: Adolescent 5, 6, and 7.

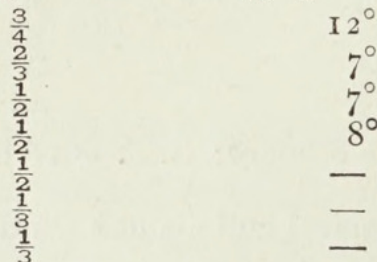

P. T. $=\frac{1}{2}$ hour ; L. T. $=5$ hours.

Stage: Adolescent 8.
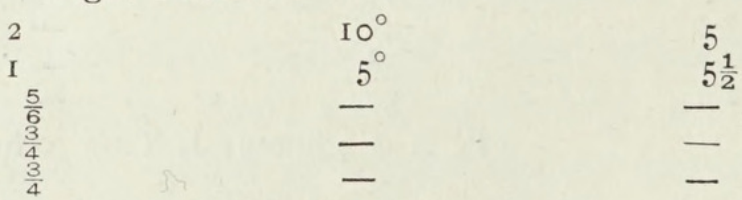

P. T. $=\mathrm{I}$ hour ; L. T. $=5 \frac{1}{2}$ hours.

Stage: Adolescent $\frac{2}{3}$ (approx.).
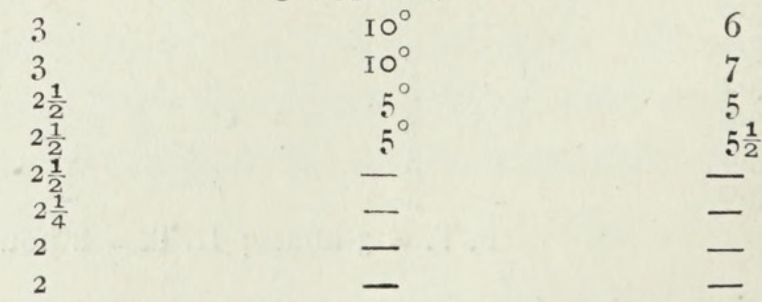

P. T. $=2 \frac{1}{2}$ hours ; L. T. $=5 \frac{3}{4}$ hours.
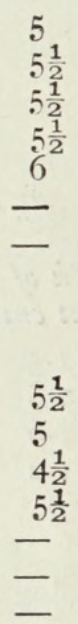

$\frac{1}{2}$

$5 \frac{1}{2}$

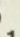

$5 \frac{1}{2}$

7

$5 \frac{1}{2}$ 
Stage: Adolescent $\frac{3}{4}$ (approx.).

\begin{tabular}{|c|c|c|c|}
\hline $\begin{array}{l}\text { Length of frond } \\
\text { in } \mathrm{cm} \text {. }\end{array}$ & $\begin{array}{l}\text { Period of stimu- } \\
\text { lation in hours. }\end{array}$ & $\begin{array}{l}\text { Angle of } \\
\text { curvature. }\end{array}$ & $\begin{array}{l}\text { Latent time } \\
\text { in hours. }\end{array}$ \\
\hline $\begin{array}{l}\text { I } 7.5 \\
16.2\end{array}$ & $\begin{array}{l}3 \frac{3}{4} \\
3 \frac{1}{2}\end{array}$ & $\begin{array}{r}10^{\circ} \\
7^{\circ}\end{array}$ & $\begin{array}{l}6 \\
6 \frac{1}{2}\end{array}$ \\
\hline 17.0 & $\begin{array}{l}J_{2} \\
3 \frac{1}{2}\end{array}$ & $7^{\circ}$ & $6 \frac{2}{2}$ \\
\hline 16.5 & $\begin{array}{l}3 \\
2 \frac{1}{3}\end{array}$ & 二 & $\bar{I}$ \\
\hline $\begin{array}{l}\text { I } 8 \cdot 7 \\
\text { I } 9 \cdot 5\end{array}$ & $\begin{array}{l}2 \frac{1}{2} \\
2 \frac{1}{2}\end{array}$ & - & $\bar{z}$ \\
\hline \multicolumn{4}{|c|}{$\begin{array}{l}\text { P. T. }=3 \frac{1}{2} \text { hours ; L. T. }=6 \frac{1}{4} \text { hours. } \\
\text { Stage: Adolescent } \frac{4}{5} \text { (approx.). }\end{array}$} \\
\hline \multirow[t]{2}{*}{$30 \cdot 0$} & $\begin{array}{l}\text { Stage: Adole } \\
\quad 4 \frac{1}{2} \\
\text { P. T. }=4 \frac{1}{2} \text { hour }\end{array}$ & $\begin{array}{l}\text { (approx.). } \\
5^{\circ} \\
=7 \text { hours. }\end{array}$ & 7 \\
\hline & Stage : Adole & (approx.). & \\
\hline $\begin{array}{l}\mathrm{I} 3.5 \\
32.0\end{array}$ & $\begin{array}{c}6 \\
5 \frac{1}{2} \\
\text { P.T. }=6 \text { hours; }\end{array}$ & $\frac{5^{\circ}}{8 \text { hours. }}$ & -8 \\
\hline
\end{tabular}

From the above tables it will be seen the presentation time is eight hours at a very early stage in the life of a frond, and decreases during its development until it reaches a minimum of half an hour, when the fifth to seventh pairs of leaflets are unfolding, rising again until all irritability to gravity ceases, when only the rudiments of the last two or three pairs of leaflets remain in the apical coil. Towards the end of its existence geotropic response is expressed by a twist of the rachis in its own plane, since the strong epinastic curvature taking place at this time seems to prevent any upward movement of the frond.

The above facts are shown graphically (p. 60) by plotting the presentation times and latent times as ordinates, and the stages of the frond as abscissae. The latter must of necessity be somewhat arbitrary, and can only correspond approximately with periods of time, as the rate of growth of a frond depends largely on temperature, which could not be kept constant through the six weeks or so of its development.

In the course of the work it was found that the presentation time in the Late Adolescent stages bore a more constant relation to the proportion of leaflets unfolded than to the actual number; hence the later stages are represented as fractions which express approximately the ratio of the number of leaflets unfolded to the total number possessed by the frond.

The curve for latent time has been plotted from the average of the figures in column 4 of the tables. It follows in general the curve for presentation time, being similarly affected by the stage of development of the frond, but not nearly to so great an extent, since its range is only sixteen to five hours as against eight hours to half an hour. This seems to be in accordance with the view expressed by Jost, ${ }^{1}$ that distinct sets of phenomena are involved in perception and reaction. 
6o Waight.-On the Presentation Time and Latent Time for

As 'previously described, ${ }^{1}$ the frond of Asplenium bulbiferum passes through a grand period of growth whose maximum under favourable conditions is I-I. $8 \mathrm{~cm}$. a day at adolescent stages. ${ }^{2}$. The increments are shown separately in the graph as ordinates corresponding with the same stages

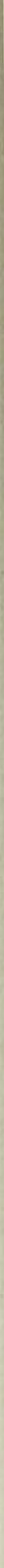

of frond development. This brings out the fact that though response to gravity ceases while the frond is still growing, the presentation time is least when growth is most rapid. Thus maximum growth is associated with minimum presentation time, and hence with maximum geotropic irritability, in so far as the one is a true measure of the other.

1 Prankerd: loc. cit., p. I 44 .

${ }^{2}$ One $\mathrm{cm}$. is also approximately the interval between each pair of leaflets at the time of their unfolding, hence about one pair a day are produced at $15^{\circ}-20^{\circ} \mathrm{C}$. 
Reaction to Gravity in Fronds of Asplenium bulbiferum. 6I

\section{SUMMARY.}

I. The fronds of Asplenium bulbiferum exhibit a grand period of irritability to gravity as measured by presentation time. This corresponds with the stage of development of the frond and not directly with its age or length.

2. At $20^{\circ} \mathrm{C}$. and 85 per cent. humidity the presentation time decreases from eight hours at a very early stage of development to a minimum of half an hour when the fifth to seventh pairs of leaflets are unfolding. It then rises to about six hours, when response to gravity ceases, a little before the frond is mature.

3. The latent time shows a range of sixteen to five hours and is also affected by the stage of the frond, but to a much less extent than the presentation time. The ratio between the two periods increases until both are at their minimum value, when it again decreases.

It is hoped to extend the present work to other ferns, and to ascertain the effect of temperature and other factors upon the time periods studied.

My thanks are due to Mr. Lacey, of the South-Western Polytechnic, and Prof. R. C. Maclean, of Cardiff University, for the loan of excellent klinostats, and to Prof. W. Stiles for affording me the opportunity of carrying out this research in his laboratory. I also wish to thank Miss Prankerd for all her help and kindness, without which it would have been quite impossible for me to have done this work. 


\section{$2 \mathrm{BHL}$ Biodiversity Heritage Library}

Waight, F. M. O. 1923. "On the presentation time and latent time for reaction to gravity in fronds of Asplenium bulbiferum." Annals of botany 37, 55-61. https://doi.org/10.1093/oxfordjournals.aob.a089836.

View This Item Online: https://www.biodiversitylibrary.org/item/270686

DOI: https://doi.org/10.1093/oxfordjournals.aob.a089836

Permalink: https://www.biodiversitylibrary.org/partpdf/319067

\section{Holding Institution}

New York Botanical Garden, LuEsther T. Mertz Library

\section{Sponsored by}

BHL-SIL-FEDLINK

\section{Copyright \& Reuse}

Copyright Status: Public domain. The BHL considers that this work is no longer under copyright protection.

This document was created from content at the Biodiversity Heritage Library, the world's largest open access digital library for biodiversity literature and archives. Visit BHL at https://www.biodiversitylibrary.org. 